\title{
Bank Characteristics and Procyclicality: A Theoretical Approach
}

\author{
Marie-Sophie Gauvin \\ Université de Bretagne Sud, Vannes, France \\ Email: marie.sophie.gauvin@gmail.com \\ Received 11 July 2014; revised 9 August 2014; accepted 19 August 2014 \\ Copyright (C) 2014 by author and Scientific Research Publishing Inc. \\ This work is licensed under the Creative Commons Attribution International License (CC BY). \\ http://creativecommons.org/licenses/by/4.0/

c) (i) Open Access

\section{Abstract}

The 2007-2008 crisis highlighted liquidity management troubles. We witness a real estate asset price boom during the pre-crisis period and a difficulty for banks to raise funding afterwards. Consequently, bank choices in response to the conduct of the monetary policy along the cycle can be studied. Despite usual financial accelerator, the excessive (lack of) confidence of banks in the upward (down) phase explains procyclical balance sheet movements. Moreover, the monetary policy effects on bank behaviors vary according to their initial specifications. From a theoretical point of view, this paper examines the response of the banking sector to monetary authorities impulses, in function of their initial characteristics. So, the paper highlights a theoretical model, based on accounting identities, in which banks are distinguished in different categories according to their level of capitalization and liquidity. The principal result is that the less capitalized and liquid banks have more procyclical behaviors.

\section{Keywords}

Banking Sector, Monetary Policy Transmission, Equities, Liquidity

\section{Introduction}

Financial crises, characterized by an asset price bust, usually follow a euphoric phase conducive to an asset price boom. Like most crises, the 2007-2008 episode appears in the aftermath of a high under-estimation risk period (Kling, 2009; Nijskens \& Wagner, 2011). The 2007-2008 crisis emerged in a context of major financial innovations associated with financial instability. Financial innovations, more particularly securitization, paved the way for a risk transfer making it difficult to trace (Brunnermeier, 2009; Duffie, 2008). The softest regulation involved an arbitrage from banks in favor of securitized assets, and thereby increased leverage (Geanakoplos, 2010) and financial accelerator (Adrian, Estrella, \& Shin, 2010). In the upward phase of the cycle, the preference for risky 
assets is, for example, consistent with the increase in the amount of commercial papers (which are liquid in good times but illiquid in bad times) in the United States, that doubled between the period 2004 and 2007. In contrast, after the crisis, banks tended to opt for safe assets (Gorton \& Ordonez, 2013), especially on account of their higher risk aversion. Contrasting 2007-2008 crisis, within the context of the Eurozone debt crisis, we can witness a flight to quality with a sharp increase in deposit facilities from July 2011 to December 2011. The 2007-2008 crisis is reminiscent in many aspects of the 1907 panic (Bernanke, 2013). Funding pressures boosted fire sales, resulting in an asset price sharp decrease. In both cases, the crisis occurred after a period of innovations (1907-trusts and newly securitization), which went out of control. Moreover, in both cases, the issue of regulation is on the agenda. Indeed, Bâle III recommendations have recently tried to reduce the build-up of risks prior to a crisis, especially with countercyclical measures. The significance of bank equities and liquidity face to shocks also implies new considerations regarding prudential policy.

All in all, throughout the paper, a theoretical model, that takes into account the relationship between monetary policy and banking, is implemented. This theoretical model involves specifying accounting identities relating to a balance sheet. New transmission channels are highlighted with a demonstration of banks' preferences. Even if the impact of prudential regulation is considered, the model highlights especially the influence of monetary policy via the risk taking channel. Further, we show that banks' behaviors would differ according to their initial characteristics. In other words, well capitalized and highly liquid banks prior to a crisis would take less risks and would be more resilient. We also note that the bank size, and especially its combination with the level of equities, is relevant in the transmission mechanism of monetary policy.

The remainder of the paper is structured as follows. In the next section, the banks' characteristics, that can influence the relationship between monetary policy and banks, are identified. The third section outlines a theoretical model developed in Gilles, Gauvin, \& Huchet (2013). Next, the model is extended by including banks' characteristics, and especially banks' equities and liquidity. And finally, the various ways of integrating these elements in the regulation are discussed.

\section{Survey}

The credit activity plays a major part in financial instability. In response to a monetary policy tightening, in order to face declining reserves, banks can favorably reduce the credit supply (or liquidate assets) at the expense of issuing liabilities with a high interest rate. The bank capital channel reinforces this mechanism and draws the following conclusion: faced with the cost of issuing liabilities, the monetary policy tightening is all the more costly than the level of equities is low (when there is a solvency ratio). Transmission channels become gradually more complex, due to the impact of interest rates on risk-taking (Ciccarelli, Maddaloni, \& Peydro, 2010). According to the risk-taking channel, Verona, Martins, \& Drumond (2013) show that the U-S boom-bust was caused, not only by too low for too long interest rates, but also by excessive optimism and a failure of agents to anticipate the extent of the unusually favorable economic conditions. Credit, risk-taking and bank capital channels are closely linked. Equity requirements provide an opportunity cost to banks that favor-at the expense of productive loans - the risk exposition and securitization (Cardone-Riportella, Samaniego-Medina, \& Trujillo-Ponce, 2010), a fortiori if interest rates are sustainably low, financial innovations attractive, and if a regulatory capital arbitrage is possible.

These new channels would be more or less pronounced according to the features of banks. Within the banking sector, individual banks adopt heterogeneous behaviors with respect to their characteristics. First, the level of equities can change the impact of monetary policy changes (Van den Heuvel, 2002, 2006) since it influences the ability of granting loans. When monetary policy tightens, a less capitalized bank is less able to absorb potential losses, so it grants fewer loans. Moreover, less capitalized banks would further increase their leverage in good times (Dell' Ariccia, Laeven, \& Marquez, 2011). On the contrary, more capitalized banks could be more risk averse and more efficient in the selection of borrowers (Mésonnier, 2005). And conversely, they are more capitalized because they are initially more careful. In addition, equity would help increase market shares of banks (Berger \& Bouwman, 2013). To explain the evolution of bank loans, Gambacorta \& Mistrulli (2004)—-thanks to a generalized method of moment estimation on Italian banks over the period 1999-2001—show that the monetary policy transmission depends on the level of bank equities. They primarily choose a special variable; the excess capital, namely the equities that banks prefer to have beyond the regulatory minimum. Their findings bear out that more capitalized banks are less dependent on regulatory constraints, so they grant more credits, whatever the 
phase of the cycle is. In other words, less capitalized banks would take more risks (Delis \& Kouretas, 2011).

Bank behaviors also differ according to their level of liquidity. Less liquid banks depend more on shocks (Kashyap \& Stein, 2000). If the interbank market dries up, the value of assets plummet, thus a more liquid bank can further maintain its loan activity given its higher stock of excess reserves. A contrario, a less liquid bank is compelled to ration credit. Altunbas, Gambacorta, \& Marques-Ibanez (2012) show that well capitalized and highly liquid banks (in the European Union (15) and United States) suffered a lower level of erosion of their solvency during the 2007-2009 financial crisis. In addition, these banks continued to lend compared to other banks (Cornett et al., 2011). Other characteristics, like the size, can influence bank behavior. Indeed, it is easier for larger banks to raise funding regardless of the cycle phase, so they are more independent on monetary policy changes. However, this easier access to markets can also entail a preference for risky assets. To put it, the size of banks has a heterogeneous effect on bank risk-taking (Brissimis \& Delis, 2010; Delis et al., 2011) (i.e. Too Big to Fail matters). Gabriel Jiménez et al. (2009) test the effect of short term interest rates on the risk-taking of Spanish banks over the period 1984-2006. According to them, the impact of monetary policy on risk-taking again depends on bank characteristics, and especially on their level of equities and liquidity. Brissimis \& Delis (2010) test the effect of monetary policy on the evolution of loans, on risks and profitability concerning commercial banks in the United States and in the first twelve countries of the Eurozone over the period 1994-2007. Here, the banks that take the highest risk, are the least capitalized and liquid but also the smallest. According to this study, the size could be negatively correlated to the risk-taking. Nevertheless, in other studies, especially that of Jiménez et al. (2009), the size is not significant, so justifying the need of a theoretical underpinning.

Finally, the impact of monetary policy on banks would be higher if bank chose securitized assets (Maddaloni \& Peydro, 2010). The monetary transmission would depend on new factors like the business model change. Gambacorta \& Marques-Ibanez (2011) show that securitization altered the mechanism of monetary transmission at the pre-and post-crisis level. According to Altunbas, Gambacorta, \& Marques-Ibanez (2007), the shift from the "Originate to hold" system to the "Originate to distribute" one would change banks' ability to distribute credits. According to them, banks that have a high share of securitized assets relative to the total of assets, are the least liquid and the least capitalized. So, the positive relationship between securitization and risk-taking is obvious.

The aim of the paper is to present a theoretical model in which bank preferences are procyclical, at the detriment of productive loans. The model also highlights that this phenomenon is more or less accentuated according to initial bank characteristics, especially equities and liquidity. The size is also determinant but its effect is heterogeneous.

\section{Outline of the Model}

The core model presented in this paper departs from Gilles, Gauvin, \& Huchet (2013) essentially by using an analysis based on the observation of the balance sheet of the banking sector. Here, we added a differentiated analysis of bank categories according to their initial characteristics. In the baseline model, banks optimize their choices and maximize their profit in function of a monetary policy change. The aim is to analyze the reaction of banks by considering the evolution of their balance sheet. This work is consistent with the financial instability hypothesis (Minsky, 1982), but also with Bernanke, Gertler, \& Gilchrist’s finding (1996) on the financial accelerator and the questioning of the Modigliani-Miller theorem. A balance sheet analysis from the bank side is therefore necessary, on the basis on Adrian and Shin (2010) and Kiyotaki \& Moore (1997). Finally, this model is quite similar to that of Choulet \& Quignon (2010), who develop a model of portfolio choices with just two assets and introduce the effect of capital requirements.

Let's provide a brief outline of the model. Two agents are considered: the Central bank and the banking sector. To capture the action of the Central bank, the interest rate is considered complying with the Taylor rule. When inflation is too high, the Central bank increases the interest rate and conversely. So the latter is an indicator of the macroeconomic situation and it is a key element to obtain a feedback on the banking sector in response to the action of the Central bank. The aim of the banking sector is to maximize its profit ${ }^{1}$. As the net yield of the banking sector portfolio $R_{P}$ is composed of $\sum_{i=1}^{N} R_{i}=r_{i}-r_{B C}$ and $a$, banks' choices are determined by the monetary policy via the interest rate $r_{B C}$ and risk aversion, which is function of asset prices (Pepin, 2011). So the bank decisions are function of an exogenous variable (the official interest rate) and an endogenous variable (the

\footnotetext{
${ }^{1} \max \left[U\left(R_{P}, \sigma_{P}\right)=R_{P}-a \sigma_{P}^{2}\right]$. With $P$ the assets portfolio, $R_{P}$ its net yield $\left(R_{P}=\sum_{i=1}^{N} R_{i}\right)$, and $a$ the risk aversion coefficient.
} 
risk aversion). The interest rate is indeed set in function of aggregated variables which are not considered in the banking sector balance sheet (GDP and inflation) and the risk aversion is function of asset prices (that are accounted for in the balance sheet). The relationship between the Central bank and the banking sector, and so the reaction of the banking sector, depend on the cycle: The interest rate is supposed to be low (high) in the ascending (descending) phase of the cycle. The upward phase is noted I and the descending phase II.

Three periods are considered: $t_{0}$ describes the initial balance sheet of the banking sector, in $t_{1}$, the Central bank sets its interest rates, the banking sector makes its choices, and $t_{2}$ describes the new balance sheet of the banking sector given the shock in $t_{1}$.

The balance sheet of the banking sector in $t_{0}$ is made up of three assets: $I_{1}$ is a safety asset (e.g. Treasury Bond), $I_{2}$ is a claim for a productive project (e.g. corporate bonds) and $I_{3}$ is a speculative asset unrelated to real activity (e.g. assets to financial sector). On the liability side, we considered the equities $K$ and the debts $D$ (respectively with a part $\alpha$ of assets for the equities, that is to say the regulatory solvency ratio, and $(1-\alpha)$ for debts) (cf. Table 1$)$. Note that the asset $I_{1}$ represents an insurance against the liquidity risk. It is preferred collateral for refinancing operations by the Central bank, which implies that banks have to hold it with a minimum of a share $\beta$ of debts: $I_{1} \geq \beta D$.

Let's summarize the hypothesis of the model. First, we assumed that the risk aversion ${ }^{2}$ of banks is a negative function of the past asset prices: $a_{t_{1}}=a\left(\mu_{t_{0}}\right)$, with $\frac{\partial a_{t_{1}}}{\partial \mu_{t_{0}}}<0 \quad\left(\mu_{i}\right.$ represents a price effect on the assets $I_{i}$ recorded at fair market values) ${ }^{3}$.

The net offer of funding $\rho_{i}$ depends negatively on risk aversion: $\rho_{t_{2}}=\rho\left(a_{t_{1}}\right)$ with $\frac{\partial \rho_{t_{2}}}{\partial a_{t_{1}}}<0$

The growth of assets from $t_{0}$ to $t_{2}$ includes a yield $R_{i}$, where $0<R_{i}<1$ is a net yield, i.e. the difference between the yield of the claim $r_{i}$ and the bank's funding cost, which amounts at least to the interest rate of the central bank $r_{B C}: R_{i}=r_{i}-r_{B C}$. In addition, according to the VaR tool, a high (low) variance $\sigma_{i}^{2}$ implies that the asset $I_{i}$ is risky (low risky).

If we compare the productive asset $I_{2}$ and the speculative one $I_{3}, I_{3}$ is more profitable $\left(R_{1}=0<R_{2}<R_{3}<1\right)$ but more risky $\left(\sigma_{1}^{2}=0<\sigma_{2}^{2}<\sigma_{3}^{2}<1\right)$ and needs more equities $\left(\alpha_{1}=0<\alpha_{2}<\alpha_{3}\right)$, so we assumed that neither of them is preferable to the other: $R_{2} / \sigma_{2}^{2}=R_{3} / \sigma_{3}^{2}$ et $R_{2} / \alpha_{2}=R_{3} / \alpha_{3}$. Note that this hypothesis is based on Choulet and Quignon's works (2010), that develops a model of portfolio choices with two assets. So the preferences of banks are observable thanks to the variable $\mu$.

Asset yields are higher in the ascending phase: $R_{i}^{I}>R_{i}^{I I} \forall i=2 ; 3$

The demand for assets exceeds the offer in the ascending phase so:

$$
\rho^{I}>1 \text { et } \rho^{I I}<1 \text { and }(\mu \rho)^{I}>1 \text { et } 0<(\mu \rho)^{I I}<1
$$

Considering these hypotheses, after the change of monetary policy in $t_{1}$.

So, the assets of the bank balance sheet in $t_{2}$ take into account the variation from $t_{0}$ and their yield ( $i=2,3$, the asset $I_{1}$ has no yield). The specific expression of the assets $I_{i}$ is the following:

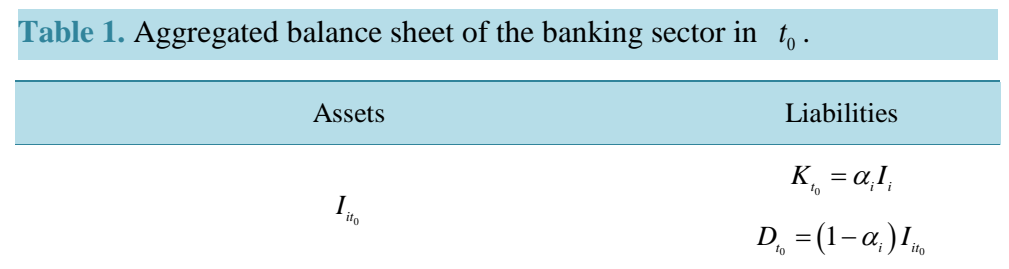

\footnotetext{
${ }^{2}$ In this paper, we consider that, even if risk aversion is an intrinsic element of the investor nature, it also depends on the level of uncertainty, so it can vary over the business cycle (it refers to the notion of "risk appetite").

${ }^{3}$ If there is a surplus demand (or offer), the volume of assets, recorded as fair value, is augmented (decreased) because of a price effect that is included in a coefficient $\mu_{i}: \mu_{i}>0$, with, for the: $\mu_{i}\left\{\begin{array}{l}<1 \text { si } \rho_{i}<1 \\ >1 \text { si } \rho_{i}>1 \text {. } \\ =1 \text { si } \rho_{i}=1\end{array}\right.$
} 


$$
I_{i t_{2}}=I_{i t_{0}}+\rho_{i} I_{i t_{0}}+R_{i} I_{i t_{0}}
$$

On the liabilities side, equities $\left(K_{t_{2}}\right)$ and debts $\left(D_{t_{2}}\right)$ are respectively composed by a share $\alpha_{i}$ and $\left(1-\alpha_{i}\right),(i=2,3)$ of assets and their variation from $t_{0}$ is contained in $\rho$. Finally, yields of assets $R_{i}$, $(i=2,3)$ appear in RAN.

So, considering all the hypotheses concerning assets and liabilities, the aggregated balance sheet of the banking sector in $t_{2}$ can be described in Table 2 .

From this balance sheet, we can observe some indicators of resilience and performance of the banking sector. For example, the profitability is expressed by the Return On Equity (Net income/equity) (with RAN the retained earnings):

$$
\frac{\operatorname{RAN}_{\mathrm{t}_{2}}}{K_{t_{2}}}=\frac{R_{i}\left(I_{2, t_{0}}+I_{3, t_{0}}\right)}{\alpha_{i}\left[\left(I_{2, t_{0}}+I_{3, t_{0}}\right)+\rho\left(I_{2, t_{0}}+\mu I_{3, t_{0}}\right)\right]}
$$

The contagious risk can be understood thanks to the leverage (Debts/Capital):

$$
\frac{D_{t_{2}}}{K_{t_{2}}}=\frac{\left(1-\alpha_{i}\right)\left[\left(I_{2, t_{0}}+I_{3, t_{0}}\right)+\rho\left(I_{2, t_{0}}+\mu I_{3, t_{0}}\right)\right]+I_{1, t_{0}}\left(1+\rho_{1}\right)}{\alpha_{i}\left[\left(I_{2, t_{0}}+I_{3, t_{0}}\right)+\rho\left(I_{2, t_{0}}+\mu I_{3, t_{0}}\right)\right]}
$$

The ratio of capital (Capital/Assets) enables us to assess the individual risk:

$$
E R_{t_{2}}=\frac{K_{t_{2}}}{I_{1 t_{2}}+I_{2 t_{2}}+I_{3 t_{2}}}=\frac{\alpha_{i}\left[\left(I_{2, t_{0}}+I_{3, t_{0}}\right)+\rho\left(I_{2, t_{0}}+\mu I_{3, t_{0}}\right)\right]}{I_{1, t_{0}}\left(1+\rho_{1}\right)+I_{2, t_{0}}\left(1+R_{2}+\rho\right)+I_{3, t_{0}}\left(1+R_{3}+\rho \mu\right)}
$$

Last, the Central bank is also sensitive to liquidity, defined (concerning macroeconomic liquidity) by the Liquidiy/Assets ratio (independent on the volume of deposits:

$$
\frac{I_{1 t_{2}}}{I_{1 t_{2}}+I_{2 t_{2}}+I_{3 t_{2}}}=\frac{I_{1, t_{0}}\left(1+\rho_{1}\right)}{I_{1, t_{0}}\left(1+\rho_{1}\right)+I_{2, t_{0}}\left(1+R_{2}+\rho\right)+I_{3, t_{0}}\left(1+R_{3}+\rho \mu\right)}
$$

According to these ratios and the hypotheses of the model, the performance of the banking sector improves in the ascending phase whereas capitalization decreases and the risk of contagion rises. In addition, thanks to the analysis of the asset share in the two phases of the cycle, it is also showed that banks prefer risky assets in (I) and safety assets in (II). In both phases, these choices are made at the expense of productive credits.

\section{The Risk Taking of Banks According to Initial Characteristics}

The model shows that banks prefer risky assets $I_{3}$ in the upward phase of the cycle (revealed by a superior ratio $I_{3} / I_{2}$ in this phase) and prefer safe assets $I_{1}$ in the downward phase (with a superior ratio $I_{1} / I_{2}$ ). The

\begin{tabular}{|c|c|}
\hline Assets & Liabilities \\
\hline$I_{1 t_{2}}=I_{1 t_{0}}\left(1+\rho_{1}\right)$ & $K_{t_{2}}=\alpha_{i}\left[\left(I_{2, t_{0}}+I_{3, t_{0}}\right)+\rho\left(I_{2, t_{0}}+\mu I_{3, t_{0}}\right)\right]$ \\
\hline$I_{2 t_{2}}=I_{2 t_{0}}\left(1+R_{2}+\rho\right)$ & $\operatorname{RAN}_{t_{2}}=R_{i}\left(\mathrm{I}_{2, t_{0}}+\mathrm{I}_{3, t_{0}}\right)$ \\
\hline$I_{3 t_{2}}=I_{3 t_{0}}\left(1+R_{3}+\rho \mu\right)$ & $D_{t_{2}}=\left(1-\alpha_{i}\right)\left[\left(I_{2, t_{0}}+I_{3, t_{0}}\right)+\rho\left(I_{2, t_{0}}+\mu I_{3, t_{0}}\right)\right]+I_{1}$ \\
\hline
\end{tabular}
aim of this section is to show that the bank choices, supporting financial instability, depend also on their initial characteristics. In the banking sector, behaviors can be distinct. On the one hand, the interest rate has a homogenous effect on the entire banking sector but, on the other hand, the risk aversion is different from one bank to another, according to their initial balance sheet. Indeed, according to one of the hypotheses, the risk aversion $a$ 
depends on the past asset prices and especially on the amount of the fair value assets. So, the risk aversion depends on the initial balance sheet composed of these assets. Accordingly, one could establish a relationship between the banks risk-taking and their initial characteristics.

By looking into the elements of the balance sheet, the variable $\mu$ is a major component of the ratio of capital since it appears mainly in the denominator:

$$
E R_{t_{0}}=\frac{K_{t_{0}}}{I_{1 t_{0}}+I_{2 t_{0}}+I_{3 t_{0}}}=\frac{\alpha_{i}\left[\left(I_{2, t_{-1}}+I_{3, t_{-1}}\right)+\rho\left(I_{2, t_{-1}}+\mu I_{3, t_{-1}}\right)\right]}{I_{1, t_{-1}}\left(1+\rho_{1}\right)+I_{2, t_{-1}}\left(1+R_{2}+\rho\right)+I_{3, t_{-1}}\left(1+R_{3}+\rho \mu\right)} \text { with } \frac{\partial a_{t_{1}}}{\partial \mu_{t_{0}}}<0
$$

The ratio of capital in $t_{0}\left(E R_{t_{0}}\right)$ is all the lower than the variable $\mu_{t_{0}}$ and the amount of speculative assets $I_{3}$ is high. Furthermore, the risk aversion is all the lower than the variable $\mu_{t_{0}}$ is high.

Besides, the growth in outstanding assets between $t_{0}$ and $t_{2}$ is a decreasing function of the risk aversion: $\frac{\partial \rho_{t_{2}}}{\partial a}<0$. So, this latter is also higher for a low initial level of equities: $\mu \rho_{t_{2}}$ is all the lower than $E R_{t_{0}}$ is low.

Therefore, in $t_{2}$, the less banks are capitalized, the more they prefer fair value assets. The risk taking channel is stronger for banks relatively less capitalized in $t_{0}$ since the best capitalized ones are, not only more risk averse, but also more effective to select borrowers (Mésonnier, 2005).

It is the same understanding concerning the liquidity ratio:

$$
L I Q_{\mathrm{t}_{0}}=\frac{I_{1 \mathrm{t}_{0}}}{I_{1 \mathrm{t}_{0}}+I_{2 \mathrm{t}_{0}}+I_{3 \mathrm{t}_{0}}}=\frac{I_{1, t_{-1}}\left(1+\rho_{1}\right)}{I_{1, t_{-1}}\left(1+\rho_{1}\right)+I_{2, t_{-1}}\left(1+R_{2}+\rho\right)+I_{3, t_{-1}}\left(1+R_{3}+\rho \mu\right)}
$$

First, the ratio $L I Q_{t_{0}}$ was even lower than the amount of $I_{3}$ assets (related to the variable $\mu_{t_{0}}$ ) was high. Moreover, the risk aversion is all the lower than $\mu_{t_{0}}$ is high. Thus, according to $\partial \rho_{t_{2}} / \partial a<0$, the growth in outstanding assets $\rho_{t_{2}}$ is a decreasing function of the risk aversion of banks. So, the growth in outstanding assets is higher for a low initial level of liquidity: $\mu \rho_{t_{2}}$ is all the higher than $L I Q_{t_{0}}$ is low. The preference for risky assets is stronger for less liquid banks in $t_{0}$. Generally, a more liquid bank is less procyclical and less sensitive to the monetary policy action. Indeed, this latter has a larger stock of assets so after a restrictive monetary policy it can restrict lending less (Kashyap \& Stein 2000). Moreover, after an expansionary monetary policy in the ascending phase, the liquid bank is the one that has the most diversified assets: choices are not concentrated on the risky assets whose liquidity collapses in the downward phase.

In addition to the capitalization and liquidity of banks, choices of banks with respect to their size (approached by the amount of total assets held by the banking sector) are also considered. The link exists but is not obvious according to the literature: On the one hand, the banks that have a great amount of assets can easily raise funds so they are less sensitive to shocks, and especially to monetary policy decisions. But on the other hand, large banks have better access to markets, which may encourage risky choices. In the model, we know that $\mu$ and $\rho$ are all the higher than the risk aversion $a$ is low. So the size of the balance sheet $\left[I_{1, t_{-1}}\left(1+\rho_{1}\right)+I_{2, t_{-1}}\left(1+R_{2}+\rho\right)+I_{3, t_{-1}}\left(1+R_{3}+\rho \mu\right)\right]$ is negatively correlated with the risk aversion and positively correlated with the growth in outstanding. Theoretically, we concluded that large banks take more risks. But this result is valid under the assumption about the diversification of assets. Indeed, it is assumed that no asset was better than any other since the asset $I_{3}$ was more profitable but more risky and needed more equities. Let's remember that the preferences of banks are observable thanks to the variable $\mu$. According to this hypothesis, $\rho_{2}=\rho_{3}=\rho$. So, in this case, the lower the risk aversion is, the higher $\mu$ and the size of the balance sheet are high. If we relax this assumption, the bank can choose more or less risky assets. A large bank can be less capitalized and less liquid ${ }^{4}$ but it could also make less risky choices in accordance with a wider diversification. To put it, even if the size has a significant role, we could not reach a conclusion on its relationship with risk taking. According to Berger \& Bouwman (2013), the effect of the capital would differ in bank sizes. In other words, it is not the size that influences the bank behavior but its combination with bank equities. We can conclude that the effects of monetary policy on bank choices are more or less important according to the considered

\footnotetext{
${ }^{4}$ According to the ratios of capital and liquidity, more the size $\left[I_{1, t_{-1}}\left(1+\rho_{1}\right)+I_{2, t_{-1}}\left(1+R_{2}+\rho\right)+I_{3, t_{1}}\left(1+R_{3}+\rho \mu\right)\right]$ is high, more the ratios
} are low. 
banking sector: the effects are different if the banking sector consists of high or low capitalized and liquid banks. A banking sector with a lot of low capitalized and liquid banks would react more to a monetary policy shock: a decrease in interest rates would promote a more important risk taking.

Symmetrically, a rise in interest rates can entail a credit rationing whose amplitude depends on the bank balance sheet. Indeed, banks with a high amount of risky assets $I_{3}$ would have low capital and liquidity ratios so they would be more affected by a decrease in asset prices $\mu$ in the downward phase. Moreover, if $\mu$ is low (due to a collapse of risky asset prices), the risk aversion is high. Consequently, in the downward phase, the growth in outstanding goes down and the decrease is higher for banks that have risky assets. The credit rationing in $t_{2}$ is accentuated by the flight to quality (the preference for assets $I_{1}$ ) and is higher for low capitalized and liquid banks. In other words, if banks prefer risky assets $I_{3}$ in $t_{0}$, the economic funding development (promoted by $I_{2}$ ) could be relatively important (since the least capitalized and liquid banks are those that have the most difficulty extending productive credit). To conclude, in both phases, monetary policy has all the more effects on bank choices (preference for risky assets in the upward phase and flight to quality in the downward phase) than banks are less capitalized and liquid.

Moreover, a securitized asset can be introduced in the model. Securitized assets are not backed to a productive project, so they are contained in $I_{3}$, whose characteristics change. The cost of protection (i.e Credit Default Swap (CDS) premium noted $g$ ) decreases the return $R_{3}$. To simplify, it is assumed that this premium equalizes the net returns of the assets $I_{2}$ and $I_{3}: R_{3}=r_{3}-r_{B C}-g=R_{2}$. The funding demand is increased by the introduction of the shadow banking system. Under these conditions, price effects, entailed by accounting standards, are higher concerning this type of assets: $\mu^{\prime}>\mu$. During the upward phase, the assets $I_{3}$ are more preferred than in the situation without securitization, since the wealth effect $\mu^{\prime}$ is reinforced, while the cost of required equities disappears. Consequently, regulation is less binding: $\alpha_{3}^{\prime}=0<\alpha_{2}$. In short, the preference for risky assets, in the upward phase, and the flight to quality, in the downward phase, are higher when we consider securitization. We can note that banks prefer $I_{3}$ in the upward phase even though we assumed that the returns of $I_{2}$ and $I_{3}$ were equal. Considering securitized assets, the bank choices still depend on their risk aversion and so, on their characteristics. Since the variable $\mu^{\prime}$ is an important component of the ratios of equities and liquidity, the effects of monetary policy still depend on the capitalization and liquidity of banks, and the dependence is even stronger as $\mu^{\prime}>\mu$.

To conclude, our theoretical model, based on accounting identities highlight that banks prefer risky assets (and securitized assets if we include shadow banking) in good times and tend to flight to quality in bad times. This result is even more accentuated according to initial bank characteristics: procyclicality is more important for low capitalized and liquid banks.

\section{Conclusions and Discussions}

The model presented showed that the combination of monetary policy and microprudential measures (e.g. Basel II standards) could encourage bank risk-taking by having procyclical effects. The recent crisis on global financial markets is the achievement of these excessive risks. This latter has led to several proposals aimed at strengthening the financial system in general and at encouraging more cautious lending behavior in the upward phase. The procyclicity effects have to be considered. According to Goodhart et al. (2013), capital requirements could be raised ahead of an asset price boom or bust, which could reduce bank risk-taking without limiting too severely overall credit supply. In this framework, capital requirements should be adjusted over the cycle. A countercyclical macro-prudential policy could help reduce the output gap and financial instability ${ }^{5}$. According to Papa N'Diaye (2009), the aims of the Central bank about output gap and inflation could be achieved with fewer variations of interest rates if the monetary policy was completed by a macro-prudential policy. Based on an analysis of bank behaviors in response to monetary policy, Agur \& Demertzis (2012) also highlight the need to join the monetary policy and the macro-prudential regulation. In their theoretical model, bank choices on the leverage and preference for types of assets (risky assets versus less risky assets) are the response to monetary policy. It is showed that an increase in the interest rate can reduce excessive risk-taking (according to the risk-taking channel), but, it is possible only if the bank leverage is moderated according to the size of the balance sheet. The ability of the monetary policy to limit risk-taking would depend on its association with the macro-prudential

\footnotetext{
${ }^{5}$ N'Diaye (2009) highlights the countercyclical macro-prudential policy in a theoretical model that analyses the relationship between monetary, financial and real sectors. His work consists in simulating an exogenous increase in domestic demand and comparing the reaction of the output and asset prices with and without the countercyclical regulation.
} 
regulation.

According to our model, banks favour risky assets in the upward phase and flight to quality in the downward phase, which justifies such a policy that takes into account the procyclicity. Moreover, the degree of risk-taking depends on risk aversion and initial bank characteristics. The relationship between these characteristics and risk aversion appears mainly in the denominator of these ratios (via the variable $\mu$ ). Consequently, the regulation should take into account the role of the numerator and the denominator in the adjustment of capital and liquidity requirements. If a countercyclical capital ratio could help reduce procyclicality, its efficiency could be reduced according to the method of adjustment. Hanson, Kashyap, \& Stein (2011) share this view and propose a solution: "the regulator does not care whether the bank adjusts via the numerator or via the denominator-that is, by raising new capital or by shrinking assets." If a single bank tries to increase its capital ratio by decreasing its assets and so by cutting back on lending, other institutions can compensate. But, if a lot of institutions shrink their assets, it could cause damage to the economy via credit rationing. In this sense, Hanson, Kashyap, \& Stein (2011) propose a corrective action targeted at dollars of capital and not capital ratios' corrective action.

According to Markus Brunnermeier et al. (2009), indicators used to apply the regulation would be the average growth of credit expansion and leverage, and the mismatch in the maturity of assets and liabilities. The Basel Committee on Banking Supervision (BCBS) has developed such a countercyclical framework complying with these recommendations. Indeed, the Basel Committee proposed an additional countercyclical buffer that will range between 0 and 2.5 percent, to be implemented on a country-by-country basis. The new standards reveal some progress involving an adjustment of the bank capital in response to excess credit growth in the private sector. Indeed, according to Agénor, Alper, \& da Silva (2013), "the expansion of credit is an essential ingredient in the build-up of imbalances in the financial system." So their DSGE model reveals two policies based on a "credit growth gap" measure: a monetary policy that considers a credit-augmented interest rate rule and a macroprudential policy based on a Basel III-type countercyclical regulatory capital rule. In their opinion, these two rules may promote both economic and financial stability. Nevertheless, the credit growth as an indicator of financial instability has to be taken with caution, depending on different economies because bank credit could have a critical role in financing short term economic activity (especially in developing economies): "a rule that constrains the growth in overall credit could entaila welfare cost” (Agénor, Alper, \& da Silva, 2013).

This comment is consistent with the main conclusion of our model about the distinction between backed assets for productive projects and speculative assets. The boom-bust cycle involves more risky assets. We should highlight that the preference for risky assets in good times and the flight to quality in bad times appear at the expense of the productive credit. Consequently, a regulation that considers the credit growth without specification about its allocation could be insufficient. The macro-prudential policy should take into account the credit allocation and distinguish the different assets. In this context, Charles Goodhart (2005) proposes that a capital requirement that concerns an asset should be relative to the price evolution of this asset (e.g. a capital requirement on mortgage should be based on the increase in housing prices) (see also Goodhart \& Persaud, 2008). Moreover, in addition to the distinction of assets, institutions could be distinguished by considering their contribution to systemic risk. This contribution could then be associated to the capital requirement (Borio, 2011). After setting an "acceptable" level of risk for the system, each institution would pay for the externality that it imposes.

To put it, micro-prudential regulation should be completed macro-prudentially. The question is the way it should be implemented. Should the macro-prudential regulation be separated from the Central bank or be included? On the one hand, price stability and financial stability are complementary in good times, but they can also be in conflict (e.g. before 2007, where a long period of price stability and low interest rates encourage the financial instability). According to this, the two aims should be separated. But on the other hand, the Central bank could be the authority with the greatest facilities to supervise the macro-prudential regulation (Betbèze et al., 2011). The European Union brought an element of answer with the "Single Resolution Mechanism". Moreover, the provision of liquidity is, not only a key function of the Central bank, but also a principal component of the prevention of crises, and the macro-prudential regulation is obviously an important actor in it (Goodhart, 2011).

Procyclicity of bank behaviors, according to monetary policy decision, involves a boom bust cycle. It can entail serious crises, just as the latest one that raises the issue of a new framework of regulation. Throughout the paper, we highlighted that banks favour risky assets in the upward phase and safe assets in the downward phase, at the expense of the productive credit. Moreover, this phenomenon can be accentuated by initial bank characteristics. In the upward phase, banks would take even more risks given they are less capitalized, less liquid and have more securitized assets. The bank size is also critical in the transmission mechanism, but it is rather its 
combination with bank equities that produces an effect. Thus, some recommendations are quoted with the main idea of capital requirements adjusted over the cycle. Moreover, given the importance of bank balance sheet in the risk taking, components of the capital ratio have to be considered; regulation should stimulate the increase in the numerator (equities) and limit the cut back on lending. An extension of the model would consider the impact of a change in prudential regulation. The remaining question is the implementation of the macro-prudential policy. If Basel III or the Dodd Franck Act gets an insight into the numerous points developed, the regulation of the shadow banking system is still without proposition, and yet, without its inclusion, financial instability cannot be reduced.

\section{References}

Adrian, T., Estrella, A., \& Shin, H. S. (2010). Monetary Cycles, Financialcycles, and the Business Cycle. Staff Reports, Federal Reserve Bank of New-York, 421.

Agénor, P. R., Korey, A., \& da Silva, L. (2013). Capital Regulation, Monetary Policy and Financial Stability. International Journal of Central Banking, 9, 193-238.

Agur, I., \& Demertzis, M. (2012). Excessive Bank Risk Taking and Monetary Policy. ECB Working Paper Series, 1457, August.

Altunbas, Y., Gambacorta, L., \& Marques-Ibanez, D. (2012). Do Bank Characteristics Influence the Effect of Monetary Policy on Bank Risk? ECB Working Paper Series, 1427, March.

Altunbas, Y., Gambacorta, L., \& Marques-Ibanez, D. (2007). Securitization and the Bank Lending Channel. ECB Working Paper Series, 838, December.

Berger, A., \& Bouwman, C. (2013). How Does Capital Affect Bank Performance during Financial Crises? Journal of Financial Economics, 109, 146-176. http://dx.doi.org/10.1016/j.jfineco.2013.02.008

Bernanke, B., Gertler, M., \& Gilchrist, S. (1996). The Financial Accelerator and the Flight to Quality. The Review of Economics and Statistics, 78, 1-15.

Bernanke, B. (2013). The Crisis as a Classic Financial Panic. Speech at the Fourteenth Jacques Polak Annual Research Conference, Washington DC, November 8.

Betbèze, J. P., Bordes, C., Couppey-Soubeyran, J., \& Plihon, D. (2011). Banques centrales et stabilité financière. Rapport du Conseil d'Analyse Economique, La Documentation française, Paris.

Borio, C. (2011). La mise en œuvre d'un cadre macroprudentiel: Un juste équilibre entre audace et réalisme. Revue d'économiefinancière, 101, 157-174.

Brissimis, S., \& Delis, M. (2010). Bank Heterogeneity and Monetary Policy Transmission. ECB Working Paper Series, 1233, August.

Brunnermeier, M., Crockett, A., Goodhart, C., Persaud, A., \& Shin, H. S. (2009). The Fundamental Principles of Financial Regulation. Geneva Reports on the World Economy, International Center for Monetary and Banking Studies,.

Brunnermeier, M. (2009). Deciphering the Liquidity and Credit Crunch 2007-2008. Journal of Economic Perspectives, 23, 77-100. http://dx.doi.org/10.1257/jep.23.1.77

Cardone-Riportella, C., Samaniego-Medina, R., \& Trujillo-Ponce, A. (2010). What Drives Bank Securitization? The Spanish Experience. Journal of Banking and Finance, 34, 2639-2651. http://dx.doi.org/10.1016/j.jbankfin.2010.05.003

Choulet, C., \& Quignon, L. (2010). Régulation Prudentielle: Les enjeux d’une réforme. Conjoncture, BNP-Paribas, Département des Etudes économiques, Janvier.

Ciccarelli, M., Maddaloni, A., \& Peydro, J. L. (2010). Trusting the Bankers: A New Look at the Credit Channel of Monetary Policy. Working Paper Series, European Central Bank, 1228.

Cornett, M., McNutt, J., Strahan, P., \& Hasan, T. (2011). Liquidity Risk Management and Credit Supply in the Financial Crisis. Journal of Financial Economics, 101, 297-312. http://dx.doi.org/10.1016/j.jfineco.2011.03.001

Delis, M., \& Kouretas, G. (2011). Interest Rates and Bank Risk-Taking. Journal of Banking and Finance, 35, 840-855. http://dx.doi.org/10.1016/j.jbankfin.2010.09.032

Delis, M., Hasan, I., \& Mylonidis, N. (2011). The Risk-Taking Channel of Monetary Policy in the USA: Evidence from Micro-Level Data. Munich Personal Repec Archive Paper, 34084, October.

Dell'Ariccia, G., Laeven, L., \& Marquez, R. (2011). Monetary Policy, Leverage, and Bank Risk-Taking. CEPR Discussion Paper, 8199, January.

Duffie, D. (2008). Innovations in Credit Risk Transfer: Implications for Financial Stability. BIS Working Papers, 255, July. 
Gambacorta, L., \& Marques-Ibanez, D. (2011). The Bank Lending Channel. Lessons from the Crisis. BIS Working Papers, 1335, May.

Gambacorta, L., \& Mistrulli, P. (2004). Does Bank Capital Affect Lending Behavior? Journal of Financial Intermediation, 13, 436-457. http://dx.doi.org/10.1016/j.jfi.2004.06.001

Geanakoplos, J. (2010). The Leverage Cycle. In D. Acemoglu, K. Rogoff, \& M. Woodford (Eds.), NBER Macroeconomic Annual 2009 (pp. 1-65). Chicago: University of Chicago Press.

Gilles, P., Gauvin, M. S., \& Huchet, N. (2013). Banking Sector and Monetary Policy Transmission: Bank Capital, Credit and Risk Taking Channels. Modern Economy Journal, 4, 77-86. http://dx.doi.org/10.4236/me.2013.41010

Goodhart, C., Kashyap, A., Tsomocos, D., \& Varduolakis, A. (2013). An Integrated Framework for Analysing Multiple Financial Regulations. International Journal of Central Banking, 109-143.

Goodhart, C. (2005). Financial Regulation, Credit Risk and Financial Stability. National Institute Economic Review, 192, 118-127. http://dx.doi.org/10.1177/002795010519200111

Goodhart, C. A. E. (2011). The Macro-Prudential Authority: Powers, Scope and Accountability. OECD Journal: Financial Market Trends, 2011, 97-123. http://dx.doi.org/10.1787/fmt-2011-5k9cswn0jrr1

Goodhart, C., \& Persaud, A. (2008). A Proposal for How to Avoid the Next Crash. The Financial Times, January 31st.

Gorton, G., \& Ordonez, G. (2013). The Supply and Demand for Safe Assets. NBER Working Papers, 18732, August.

Hanson, S., Kashyap, A., \& Stein, J. (2011). A Macro-Prudential Approach to Financial Regulation. Journal of Economic Perspectives, 25, 3-28. http://dx.doi.org/10.1257/jep.25.1.3

Jiménez, G., Ongena, S., Peydro, J. L., \& Saurina, J. (2009). Hazardous Times for Monetary Policy: What Do Twenty-Three Million Bank Loans Say about the Effects of Monetary Policy on Credit Risk-Taking? AFA 2009 San Francisco Meetings Paper.

Kashyap, A., \& Stein, J. (2000) What Do a Million Observations on Banks Say about the Transmission of Monetary Policy? The American Economic Review, 90, 407-428. http://dx.doi.org/10.1257/aer.90.3.407

Kiyotaki, N., \& Moore, J. (1997). Credit Cycles. Journal of Political Economy, 105, 211-248. http://dx.doi.org/10.1086/262072

Kling, A. (2009). Not What They Had in Mind: A History of Policies That Produced the Financial Crisis of 2008. Working Paper, Mercatus Center, Fairfax: George Mason University.

Maddaloni, A., \& Peydro, J. (2010). Bank Risk-Taking, Securitization, Supervision and Low Interest Rates: Evidence from the Euro Area and the US Lending Standards. European Central Bank Working Paper, 1248, October.

Mésonnier, J. S. (2005). Capitalisation bancaire et transmission de la politique monétaire: Une revue. Banque de France, Mimeo.

Minsky, H. (1982). Can “It” Happen Again? M. E. Sharpe (Ed.), Essays on Instability and Finance, New York.

N’Diaye, P. (2009). Countercyclical Macro Prudential Policies in a Supporting Role to Monetary Policy. IMF Working Paper, November. http://dx.doi.org/10.5089/9781451874037.001

Nijskens, R., \& Wagner, W. (2011). Credit Risk Transfer Activities and Systemic Risk: How Banks Became Less Risky Individually but Posed Greater Risks to Financial System at the Same Time? Journal of Banking and Finance, 35, 13911398. http://dx.doi.org/10.1016/j.jbankfin.2010.10.001

Pepin, D. (2011). Instabilité des comportements et cycles financiers: Une relecture dans un cadre rationnel avec préférences endogènes. Document de Travail, 07, CRIEF, Université de Poitiers.

Van den Heuvel, S. (2002). Does Bank Capital Matter for Monetary Transmission? Federal Reserve Bank of New York, Economic Policy Review, 260-266.

Van den Heuvel, S. (2006). The Bank Capital Channel of Monetary Policy. The Wharton School University of Pennsylvania Meeting Papers, 512.

Verona, F., Martins, M., \& Drumond, I. (2013) (Un)anticipated Monetary Policy in a DSGE Model with a Shadow Banking System. Bank of Finland Research Discussion Paper, 4, April. 
Scientific Research Publishing (SCIRP) is one of the largest Open Access journal publishers. It is currently publishing more than 200 open access, online, peer-reviewed journals covering a wide range of academic disciplines. SCIRP serves the worldwide academic communities and contributes to the progress and application of science with its publication.

Other selected journals from SCIRP are listed as below. Submit your manuscript to us via either submit@scirp.org or Online Submission Portal.
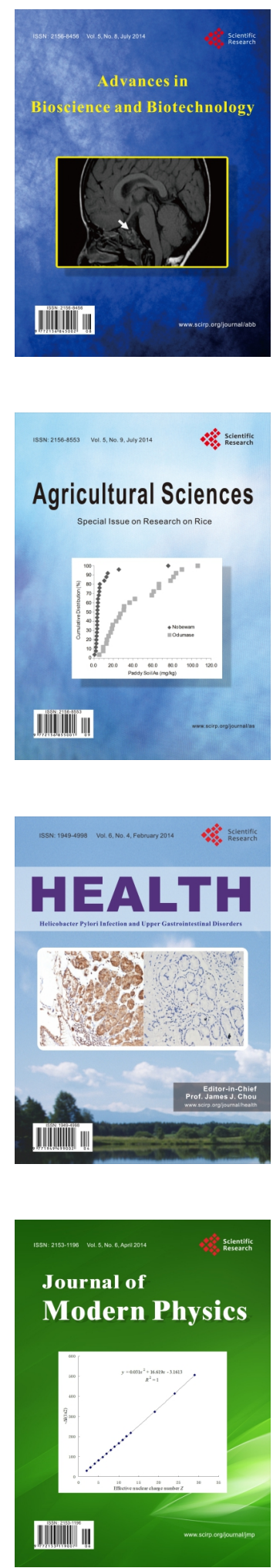
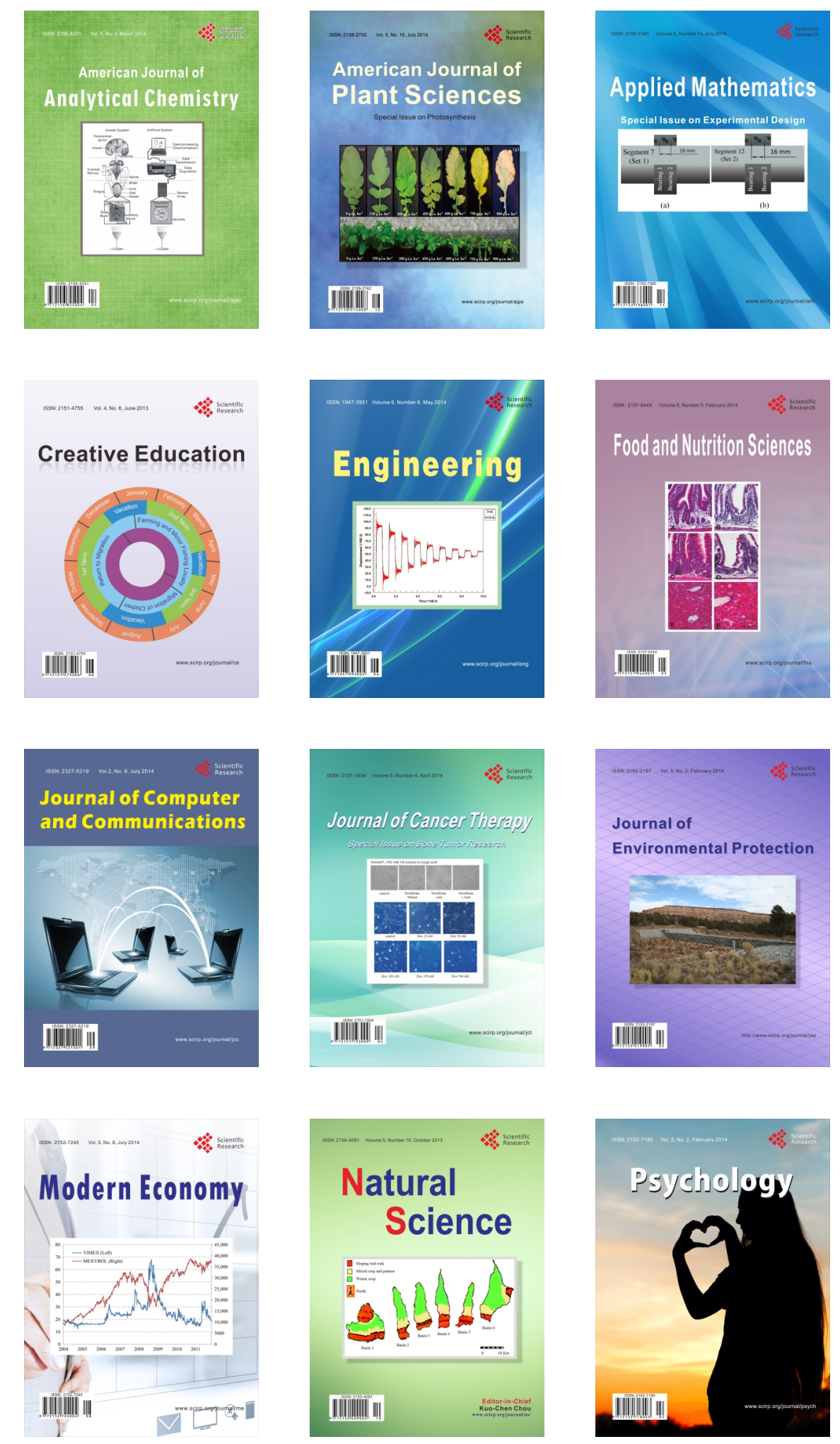